\title{
IMPACT OF HEAVY METAL TO FISH AQUACULTURE IN FLOATING NET CAGE IN CIRATA RESERVOIR, INDONESIA
}

\author{
Tri Heru Prihadi ${ }^{*}$, Murniyati*), and Idil Ardi ${ }^{*}$
}

\begin{abstract}
Utilization of Cirata Reservoir for fisheries aquaculture with floating net cage system has been increasing rapidly. Industrial waste existed along watershed brings significant heavy metal pollutant that flows and difficult to control. Consequences of such activities were reflected in the degradation of reservoir environment indicated by sedimentation, water quality degradation and fish mass mortality because of up welling. The objectives of this research were: 1) to obtain data and information on heavy metal content in Cirata Reservoir waters, and 2) to observe and understand the effect of heavy metal to the fish cultured in floating net cage to support aquaculture in floating net cage system. Water quality and fish histology analyses were the methodologies used in this research. Descriptive and laboratory analysis were carry out to analysis the data. Based on observation and descriptive analyses, the content of heavy metal in Cirata Reservoir was classified as worse. Concentration of $\mathrm{Pb}, \mathrm{Cr}$, $\mathrm{Hg}$, and $\mathrm{Cd}$ in the sample of water and tilapia digestive organ becomes fragile. Infiltration of hemoglobin cell, necrosis, degeneration and pigmentation occurred in body organs when up welling happened. Beside that, during up-welling digestive organ become easily breakable resulted in fish mass mortality in floating net cage. The affinity of hemoglobin to the toxic gas was higher than to oxygen, therefore aeration was not affective and mass mortality cannot be avoided. This was because of various events that occured to the fish and the other water biota that encompassed regular diffusion, bio-magnification, and bio-concentration to fish.
\end{abstract}

\section{KEYWORDS: floating net cages, heavy metal, fish mortality}

\section{INTRODUCTION}

Reservoir is an area for pooling water that generally is constructed from river and swamp for certain objectives. Reservoirs that has multiple functions in West Java, Indonesia are Saguling, Cirata, and Juanda-Jatiluhur Reservoir. Basically, the three reservoirs are related each other, that is Saguling Reservoir in the upstream, Cirata Reservoir in the middle and Juanda Jatiluhur at the downstream, as part of Citarum watershed system.

Rapid increase of fish aquaculture in floating net cages system in the Reservoir is due to some considerations such as follow: level of production, available water wide, resources sustainability, easy and simple in implementation, availability of technology package for floating net cage in reservoir and profitable (Hardjamulia et al., 1991). Fish aquaculture activities with floating net cage system do not require production cost for land purchase. In addition, if the reservoir experiences up welling, technically, floating net cage is easy to move, and easy to control the predator, food application in the cages is relative optimal and there is a possibility to intensify the production (Sukadi et al., 1989). Due to those reasons, fish aquaculture in floating net cage system has been rapidly increasing, particularly at Cirata Reservoir.

") Central Research Institute for Aquaculture, Jakarta, Indonesia 
Cirata Reservoir is a water environment having high possibility to be polluted by heavy metal. In the upstream, there are many industries, particularly around Saguling Reservoir and along of Citarum Rivers, as source of heavy metal pollutant. Textile industries, most of them existed along the watershed bring significant heavy metal pollutant in the form of paint and other chemical substances. The existence of heavy metal that flows into the reservoir will result in decreasing on water quality and living biota.

As result of physical and chemical parameter of heavy metal one dissolve in the water and accumulate in biota body tissue such as in plankton, epiphyte, fish, and filter feeder organism (e.g. moluscas). Through the food chain, the metal will result in biotransformation and biomagnifications to the higher level of predator. If any human consumes the organism, the impact is health problems (Afrizal, 2000).

\section{METHODOLOGY}

\section{Time and Research Location}

The research was conducted in 2005 at Cirata Reservoir, West of Java.

\section{Water Sampling}

Water sample were collected in on different depths for each station: at the surface, 4 meters, and 8 meters. For each depth, water sample was collected in duplicate. Water sample was collected using Van Dorn type water sampler. Water sample was stored in polyethylene bottle and stored at $40^{\circ} \mathrm{C}$. The analysis was conducted for water quality and heavy metal content in the fish body. The sampling was carried in three stations.

\section{Sampling of Organ Target}

Fish collected from the cages were cut open, while meat, liver and kidney were collected for organ sample. The organ sample required for heavy metal analysis was 3-5 grams of wet weight of meat, liver, and kidney (composite sample). The organ samples were collected in film bottle, and stored in a cool box.

\section{Sampling Treatment}

Measurement of heavy metal in fish organ and water samples used AAS (Atomic Absorption Spectrophotometer) in laboratory. Based on evaporation of sample solution, and then the metals content is converted to free atom (Darmono, 1995).

\section{Data analysis}

a. Measured heavy metal data were analyzed descriptively, comparing measured data with water quality standard according to PPRI No. 82, 2001.

\section{b. Concentration Factor}

Concentration factor index (FK) approach used to study difference of heavy metal content in the fish and the water (Van Esch, 1977 in Jumariyah, 2001):

$$
\mathrm{FK}=\frac{\text { Heavy metal content in Fish }(\mathrm{ppm})}{\text { Heavy metal content in water }(\mathrm{ppm})}
$$

\section{RESULTS AND DISCUSSION}

Cirata Reservoir is located at the center of Citarum watershed (between Saguling dan Juanda Reservoirs). Citarum wathersed is complex and threatened. The threat is particularly in the form of waste both from domestic and industrial sources. Soewondo \& Oginawati (2004) suggested that more than 260 tons of domestic and industrial waste are daily inflown in Citarum. Generally, the industrial liquid waste is directly discharged without any treatment. This condition furtherwill worsen water quality in Cirata Reservoir.

\section{Heavy Metal in Water, Sediment, and} Fish

In general, water quality in Cirata Reservoir based on STORET index was classified as worse, at any depth of surface, 2-meter, 4meter, and 8-meter in depth (Prihadi, 2005). Furthermore, result of heavy metal analysis showed that investigated metal such as $\mathrm{Pb}, \mathrm{Cr}$, $\mathrm{Hg}$, and $\mathrm{Cd}$ were contained in water and organ of tilapia and carp of spleen, liver, and gill, as presented in Table 1.

As indicated from Table 1 above, metal concentration in fish was much higher than that in the water. This was because of various events that occured in the fish and in the other water biota that encompassed regular diffusion, biomagnification, and bio-concentration on that fish.

\section{Condition of Fish Cultured}

From morphological perspective, fish culture in floating net cage system in Cirata Reservoir. had similar appearance as cultured in 
Table 1. Heavy metal level of $\mathrm{Pb}, \mathrm{Cr}, \mathrm{Hg}$, and $\mathrm{Cd}$ at Cirata Reservoir

\begin{tabular}{lcccc}
\hline \multirow{2}{*}{ Sample } & \multicolumn{4}{c}{ Heavy metal contend (ppm) } \\
\cline { 2 - 5 } & $\mathbf{P b}$ & $\mathbf{C r}$ & $\mathbf{H g}$ & $\mathbf{C d}$ \\
\hline Water & 0.01 & 0.01 & 0.01 & 0.02 \\
\hline Tilapia: & & & & \\
Spleen & 1.07 & 1.46 & 0.77 & 1.16 \\
Kidney & 0.52 & 0.54 & 0.53 & 0.61 \\
Liver & 0.72 & 0.76 & 0.6 & 0.82 \\
Gill & 0.36 & 0.59 & 0.22 & 0.31 \\
\hline Carp: & & & & \\
Spleen & 1.07 & 1.19 & 0.97 & 1.00 \\
Kidney & 0.54 & 0.54 & 0.48 & 0.51 \\
Liver & 0.72 & 0.89 & 0.58 & 0.70 \\
Gill & 0.36 & 0.46 & 0.30 & 0.34 \\
\hline
\end{tabular}

other locations, however, the organs were difference. In this context, organ of carp and tilapia generally shows dull in color and fragile meaning that if the organs are squeezed, they are inelastic contrary to as in healthy fish, and easy to breakdown.

According to the fragility, fragile organs such as liver, kidney and spleen were sampled for histology preparation. Histology preparation was also carried out for gill that showed dull color. Histopathology analysis showed that (refer to fish histology atlas from Hibiya, 1982): both the tilapia and carp's gill did not show a specific disorder (Figure $1 \mathrm{a}$ and $1 \mathrm{~b}$ ), indicated that toxic and hazard substance in the water did not affect gill function for respiration. In other hand, it was suggested that bio-concentration of toxic and hazard substances usually occurring in the gill was low, and did not impair the organs function.

Both tilapia and carp's liver showed disorder symptom. Tilapia's liver showed degener-

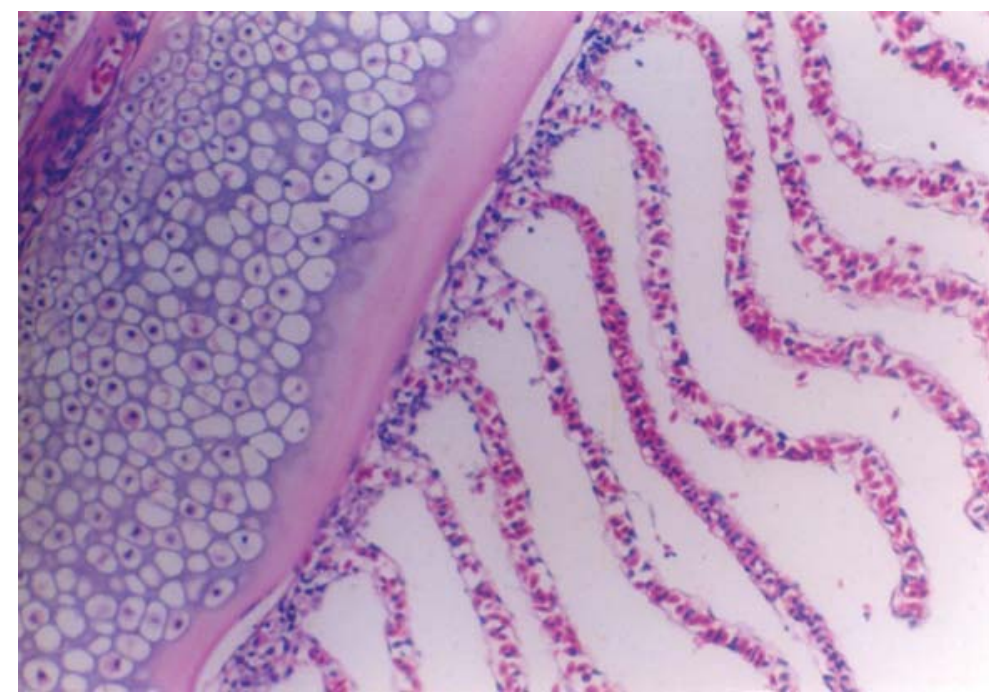

Figure 1a. Tilapia's gill $(10 \times 20)$ 


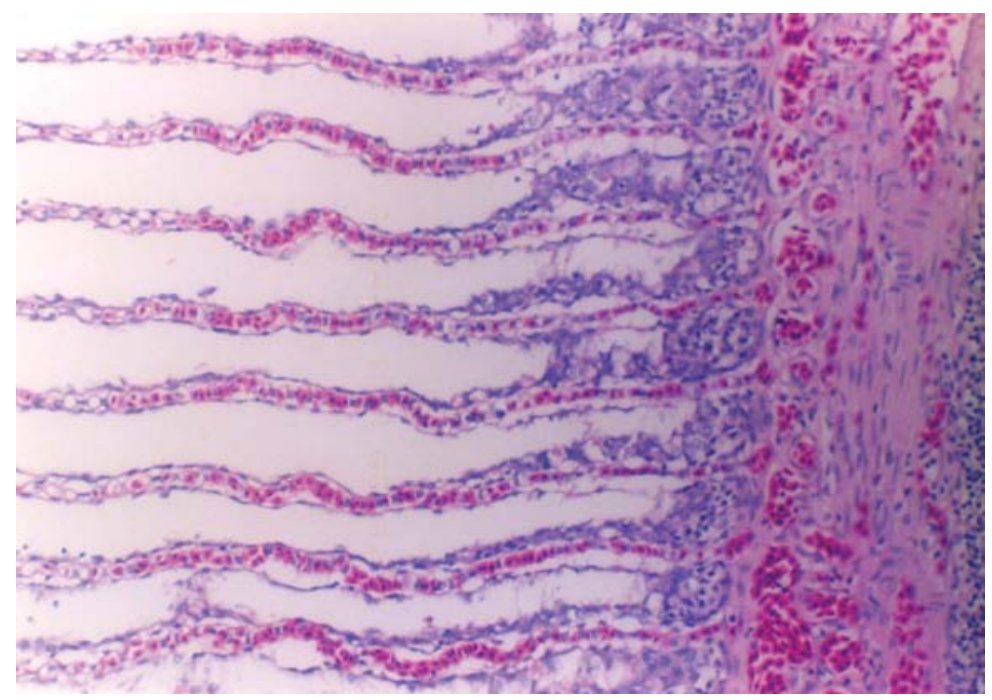

Figure 1 b. Carp's gill $(10 \times 20)$

ated cells, while part of the cells were necrosis. In addition, tilapia's liver showed infiltration of lymphocyte cells (Figure $2 a$ ). The similar condition was observed in carp's liver (Figure $2 \mathrm{~b}$ ). Occurrence of impaired liver, both in tilapia and carp, indicated that the reservoir contained toxic and hazard substances that entered to fish's organ through bio-magnification process in the food chain.

Both the tilapia and carp's kidney are shows disorder. Tilapia's liver showed degenerated cells and experiencing infiltration of lymphocyte cells, and indicated melanin pigment (Figure 3a). While Carp's liver shows degenerated cells and experienced infiltration of lymphocyte cells (Figure 3b). Impaired kidney, both in tilapia and carp, indicated that in the fish's blood, there were toxic and hazard substances that should have been filtered by the kidney.

Both the tilapia and carp's spleen are shows disorder. Tilapia's spleen shows a lot of hemoglobin fraction that indicated erythrocyte de-

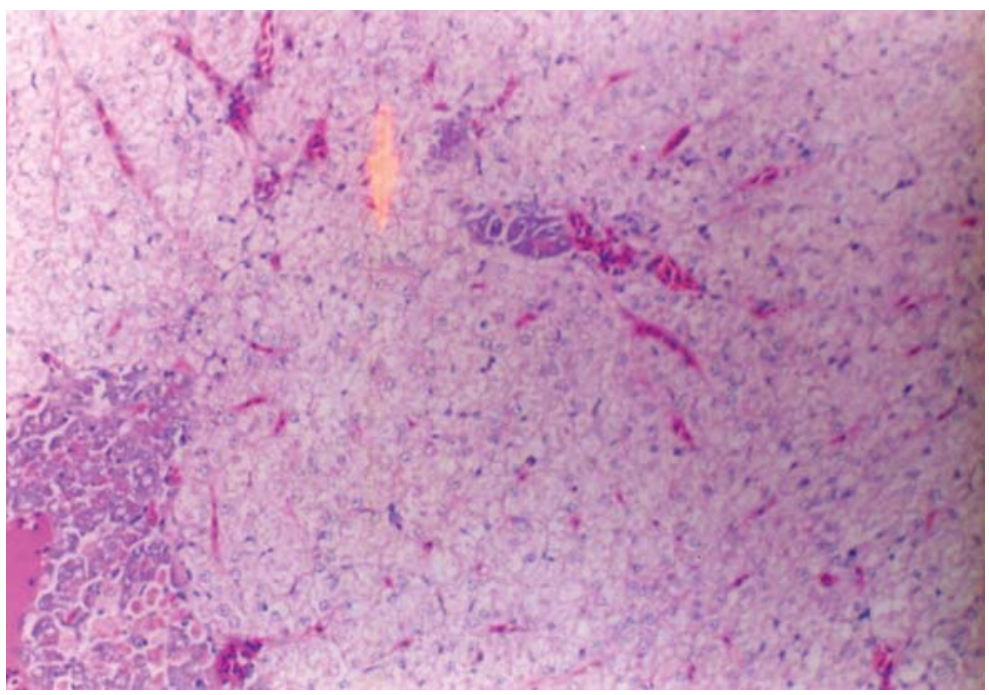

Figure 2a. Tilapia's liver ( 10 X 20) 


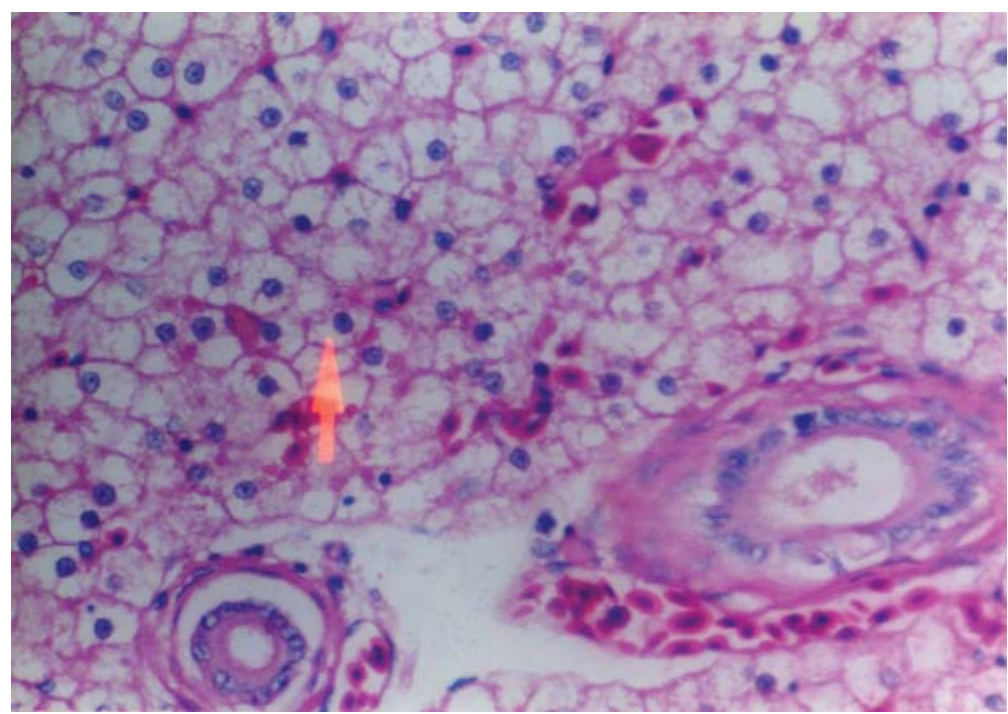

Figure $2 b$. Carp's liver ( 10 X 40)

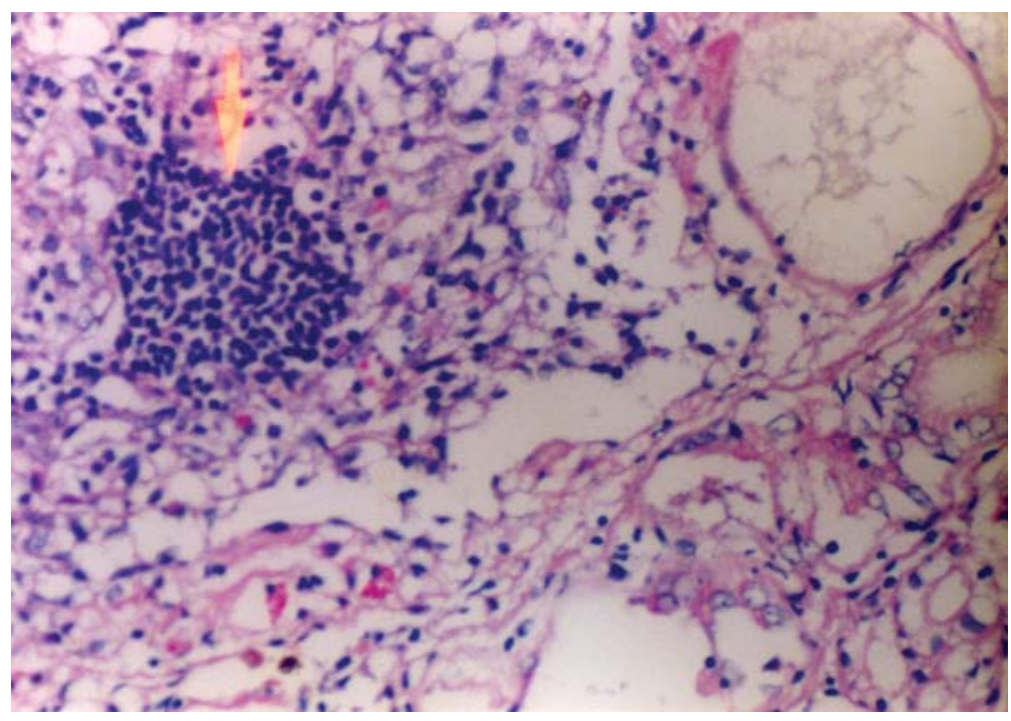

Figure 3a. Tilapia's kidney (10 X 40)

struction at the spleen (Figure 4a), while the carp's spleen experienced hyperemia (Figure $4 b)$.

Based on the observation on tissue disorder (histopathology) and high heavy metal content in the organs, it was suggested that the organ damage was caused by toxic and hazard substances from heavy metal. In the reservoir water. Mass mortality of fish cultured in floating net cage system frequently accurred, particularly in last two years. The condition was caused by up welling and the existence of toxic and hazard wastes in Cirata Reservoir. The suggestion was supported by the fact of heavy metal content such as $\mathrm{Pb}, \mathrm{Cd}, \mathrm{Hg}$, and $\mathrm{Cr}$ detected both in the water and fish's organ including spleen, liver, gill, and kidney. Even, in the organs like spleen, liver, gill, and kidney of fish cultured for three months in Cirata Res- 


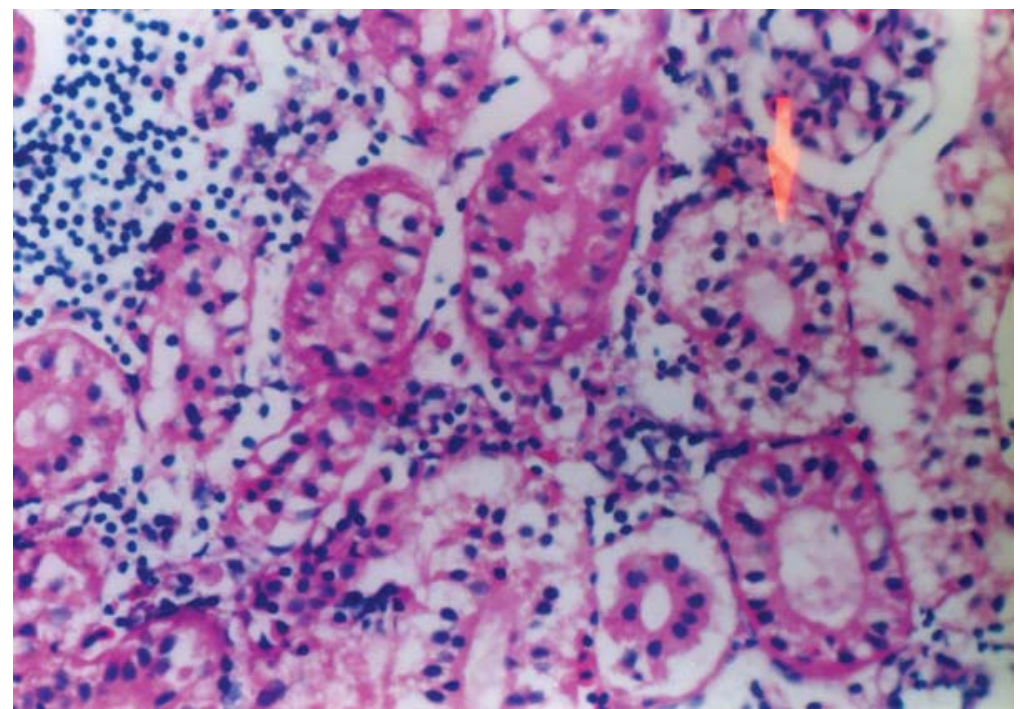

Figure 3b. Carp's kidney (10 X 20)

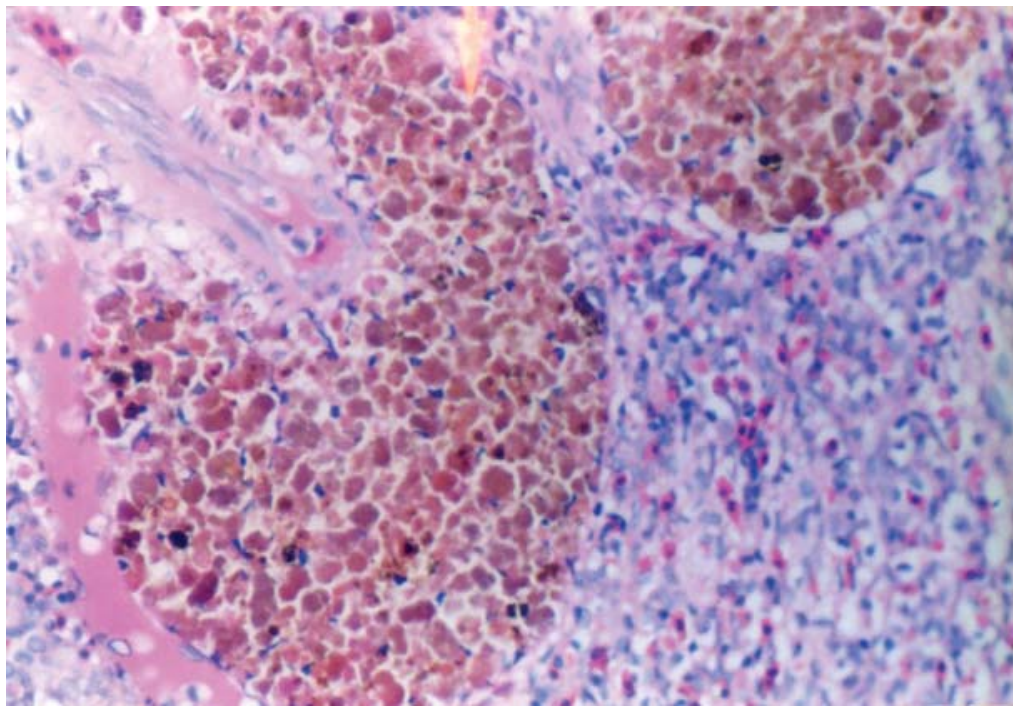

Figure 4a. Tilapia's Spleen (10 X 40)

ervoir, the concentration increased significantly. Further hand, the organs were fragile and showed various disorders (histopathology destruction). Consequently, fish cultured in floating net cage system in Cirata Reservoir were easy to die.

The existence of hardly degradable wastes, e.g. heavy metals, was also detected from COD value that the same as and higher than the BOD value. This condition indicated that waste inflow in to Cirata Reservoir consisted of organic wastes and uneaten fish food for floating net cage system. In addition, biologically hard decomposing waste was high, and the decomposition needs chemical reaction. According to Prihadi (2005), significant high waste quantity required reservoir restoration by sediment lifting or "dredging", however the efforts need hydrology study, in or- 


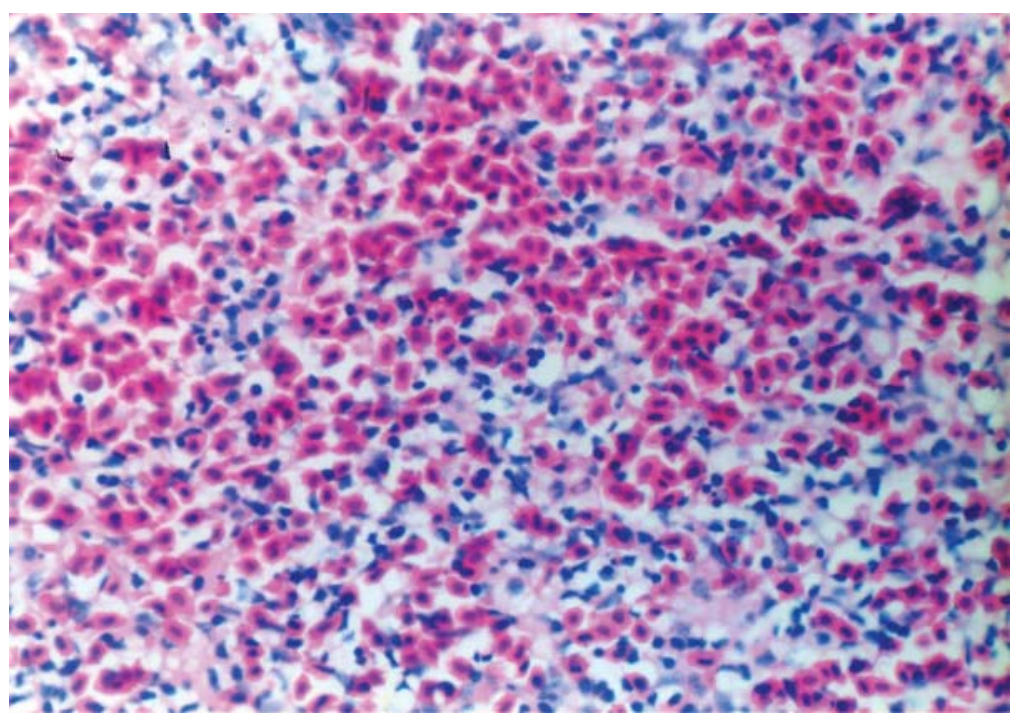

Figure 4b. Carp's Spleen (10 X 40)

der to make fisheries safe from high toxic threats and the possibility of using pollutant waste for manure.

It is necessary to conduct coordination to create a good networking among environmentalists particularly in for reservoir ecosystem, therefore, the result would be more efficient and userful on the other hand, continuous control followed by tight regulation should be implemented. Regulation established by decision makers should be strengthened and implemented both by all.

\section{CONCLUSION AND RECOMMENDATION}

Upwelling caused mass mortality of fish in floating net cage in Cirata Reservoir, toxic gasses were major couse of the mortality. The fish organs such as liver, kidney and spleen as well as digestive organ beceme more fragile coused by heavy metal content. Histology analysis also showed impaired organs. High oxygen supply or aeration did not much help because affinity of hemoglobin to the toxic gasses was higher than to oxygen, therefore, aeration is ineffective and mass mortality could not be avoided.

Good management of aquaculture is one way to get sustainable aquaculture system and controlling heavy metal flowns from up stream to the reservoir is highly recommended.

\section{REFERENCES}

Afrizal, I. 2000. Kandungan Logam Berat Cd, $\mathrm{Pb}, \mathrm{Cu}$, dan $\mathrm{Zn}$ dalam Air, Sedimen, dan Beberapa Organisme Benthos di Muara Sungai Asahan, Sumatera Utara. Skripsi. Program Studi Ilmu Kelautan. FPIK. IPB Bogor.

Darmono. 1995. Logam dalam Sistem Biologi Makhluk Hidup. Penerbit Universitas Indonesia. Jakarta.

Jumariyah. 2001. Kandungan Logam Berat Kadmium (Cd), Timbal ( $P b)$, dan Tembaga (Cu) Pada Kerang Hijau (Perna viridis L.) di Teluk Banten. [Skripsi]. Departemen Manajemen Sumberdaya Perairan. FPIK IPB. Bogor.

Prihadi, T.H. 2005. Pengelolaan Budidaya Ikan secara Lestari di Waduk. Disertasi Doktor pada Program Studi Pengelolaan Sumberdaya Alam dan Lingkungan. Pascasarjana Institut Pertanian Bogor.

Saanin, H. 1984. Taksonomi dan kunci identifikasi ikan, Jilid I dan II. Binacipta. Bandung.

Saeni, M.S. 1989. Kimia Lingkungan. Departemen Pendidikan dan Kebudayaan. Jakarta. Ditjen Pendidikan Tinggi, PAU Ilmu Hayat, IPB Bogor.

Sukadi, M.F., I.N.S. Rabegnatar, O. Praseno, Krismono, Z. Jangkaru, dan H.R. Schmittou. 1989. Petunjuk Teknis Budidaya Ikan Dalam 
Keramba Jaring Apung. Badan Penelitian Dan Pengembangan Pertanian. Pusat Penelitian dan Pengembangan Perikanan, Jakarta.
Sumantadinata, K. 1981. Pengembangbiakan ikan-ikan peliharaan di Indonesia. Sustra.

Yap, A. 2003. Keragaan Polutan di Perairan Waduk. Institut Teknologi Bandung. Bandung. 6 pp. 